\title{
ALTERAÇÕES HEMATOLÓGICAS E SOROLÓGICAS EM EQÜINOS EXPERIMENTALMENTE INFECTADOS COM Babesia equi
}

\author{
HAEMATOLOGICAL AND SEROLOGICAL CHANGES IN HORSES \\ EXPERIMENTALLY INFECTED WITH Babesia equi
}

\author{
Cristina Wetzel da Cunha ${ }^{1}$ Sergio Silva da Silva ${ }^{2}$ \\ Bárbara Lícia Osório ${ }^{3}$ Cristiana Lückemeyer Dutra ${ }^{3}$
}

\section{RESUMO}

No presente estudo são relatadas alterações hematológicas e sorológicas apresentadas por eqüinos, infectados experimentalmente com B. equi, em diferentes estágios da infeç̧ão e após esterilização quimica do parasito. Dez equilinos, clinicamente sadios e sorologicamente negativos para Babesia spp, foram inoculados com B. equi e tratados com drogas babesicidas durante o pico de parasitemia. Após o tratamento os animais foram divididos em dois grupos: portadores; que desenvolveram a fase crônica da enfermidade esterilizados, nos quais o parasito foi eliminado. Durante todo o experimento o hematócrito, a parasitemia e o titulo de anticorpos foram acompanhados, de forma a caracterizar sua dinâmica na fase aguda e na fase crônica da enfermidade, assim como após a eliminação do parasito.

Palavras-chave: babesiose eqüina, Babesia equi, diagnóstico.

\section{SUMMARY}

In the present study the haematological and serological changes showed by horses experimentally infected with $B$. equi, during different infection stages and after chemotherapy parasite sterilization, are reported. Ten horses clinically healthy and serologically negative for Babesia spp were inoculated with $B$. equi and treated with babesicidal drugs during ascending parasitemia. After the treatment the horses were separated in two groups: carriers, which developed the chronic babesial infection, and sterilized horses, which the parasites were eliminated. During the whole experiment, hematocrit, parasitemia and antibody titers were monitored to characterize its dinamics in the acute and chronical babesial infection, as well as after elimination of parasites.

Key words: equine babesiosis, Babesia equi, diagnosis.

\section{INTRODUÇÃO}

Dentre as enfermidades que afetam os eqüinos destacam-se as doenças parasitárias, onde as hemoparasitoses têm sido mencionadas como importantes causas de danos à sanidade animal com comprometimento da função eqüina. Neste contexto, a babesiose representa a parasitose de maior importância econômica na equinocultura, determinando tanto prejuizos diretos, que vão desde a queda na performance até a morte de animais, quanto indiretos, devido à restrição de comercialização e trânsito de eqüinos soropositivos em alguns pais (FRIEDHOFF, 1990; BRÜNING, 1996).

A preocupação dos criadores de cavalos com a babesiose eqüina tem exigido a atenção de veterinários com o diagnóstico da enfermidade. De uma maneira geral, o diagnóstico é realizado a partir de sinais clínicos e da avaliação de alguns parâmetros

\footnotetext{
${ }^{1}$ Médico Veterinário, MSc., Doutorando em Biotecnologia, Universidade Federal de Pelotas (UFPel), Centro de Biotecnologia, Campus Universitário, Prédio 19, 96010-900, Pelotas, RS, Brasil. E-mail: cwcunha@ufpel.tche.br. Autor para correspondência

${ }^{2}$ Médico Veterinário, MSc., Professor Assistente, Departamento de Veterinária Preventiva - UFPel.

${ }^{3}$ Graduanda em Veterinária - UFPel, Bolsista de Iniciação Científica - CNPq. Recebido para publicação em 20.08.97. Aprovado em 22.10.97
} 
do hemograma, como contagem de eritrócitos, hematócrito e contagem diferencial de leucócitos (RUDOLPH et al., 1975), associados à detecção dos parasitos na circulação (PHIPPS, 1995). Rotineiramente, a pesquisa de parasitos é feita em esfregaços sangüíneos corados. Entretanto, esta técnica apresenta algumas limitações durante infecções crônicas, onde a baixa parasitemia pode resultar em um grande número de diagnósticos falso negativos (DE WAAL, 1992; BÖSE, 1995). Nestes casos, o diagnóstico indireto, através da detecção de anticorpos específicos no soro, pode ser útil. No entanto, faz-se necessário maior conhecimento da dinâmica de anticorpos durante as diferentes fases da infecção, assim como da sua relação com os parâmetros hematológicos e clínicos utilizados no diagnóstico da enfermidade.

O presente estudo relata os valores de hematócrito, parasitemia e título de anticorpos apresentados por eqüinos infectados experimentalmente com B. equi durante diferentes estágios da infecção e após esterilização química do parasito.

\section{MATERIAIS E MÉTODOS}

Dez eqüinos entre 3 e 4 anos de idade, SRD, clinicamente sadios e sorologicamente negativos para Babesia spp pela reação de imunofluorescência indireta (RIFI) foram inoculados experimentalmente com $1,6 \times 10^{11}$ eritrócitos infectados com B. equi, por via parenteral. Os animais foram mantidos a campo e periodicamente tratados com carrapaticidas e inseticidas a base de piretróides $\left(\right.$ Butox $^{\circledR}$ ) com intervalos de 15 dias, para evitar reinfecções.

O hematócrito, a parasitemia e o título de anticorpos foram monitorados até o $102^{\circ} \mathrm{DAI}$, diariamente durante a fase aguda da infecção e semanalmente após o tratamento. Os valores de hematócrito foram obtidos pela técnica de microhematrócrito e a parasitemia estimada a partir da contagem de aproximadamente 10.000 hemácias em esfregaço sangüíneo corado com Giemsa. A determinação do título de anticorpos foi feita por reação de imunofluorescência indireta (RIFI), sendo considerados positivos títulos iguais ou maiores que 80 (CUNHA, 1993).

Durante o pico de parasitemia, entre o quinto e $11^{\circ}$ dia após a inoculação (DAI), os animais foram tratados com drogas babesicidas (OSÓRIO et al., 1995). Para análise dos dados hematólogicos e sorológicos, após o tratamento babesicida, os animais foram divididos em dois grupos: (1) portadores, com três animais que desenvolveram a fase crônica da enfermidade, e (2) esterilizados, com sete animais nos quais o parasito foi eliminado. Para comprovar o estado de portador ou esterilização do parasito, aos $103 \mathrm{DAI}$ os equinos foram submetidos à imunossupresão química com drogas corticóides (CUNHA, C.W., 1995, dados não publicados), com a finalidade de favorecer reagudizações de parasitemia em animais com infecções crônicas (OLADOSU \& OLUFEMI, 1992).

\section{RESULTADOS E DISCUSSÃO}

Todos animais inoculados desenvolveram parasitemia detectável em esfregaço sangüíneo entre o $2^{\circ}$ e o $7^{\circ}$ DAI. Considerando-se os resultados médios dos 10 animais infectados, foi observado pico de parasitemia $(0,41 \%) \quad 7^{\circ} \mathrm{DAI}$ e queda máxima no hematócrito (de $37 \%$ para $27 \%$ ) no $9^{\circ}$ DAI. Os resultados da sorologia demonstraram soroconversão em todos os animais infectados até o $6^{\circ} \mathrm{DAI}$, sendo que $30 \%(3 / 10)$ já apresentavam sorologia positiva no $3^{\circ}$ DAI.

Após 48 horas do início do tratamento babesicida, os 10 eqüinos apresentaram queda na parasitemia, seguida de resolução da fase aguda da infecção. Considerou-se, para fins de análise, o início da fase crônica aos 13 DAI, quando os três eqüinos que mantiveram-se portadores já haviam sido tratados. Os resultados médios de hematócrito, parasitemia e título de anticorpos dos dois grupos, portadores e esterilizados, estão apresentados na Tabela 1.

A fase crônica da infecção caracterizou-se pela persistência de altos títulos de anticorpos, acima de 2560 , e por parasitemia em torno de $0,01 \%$, sem alteração significativa no hematócrito (Figura 1).

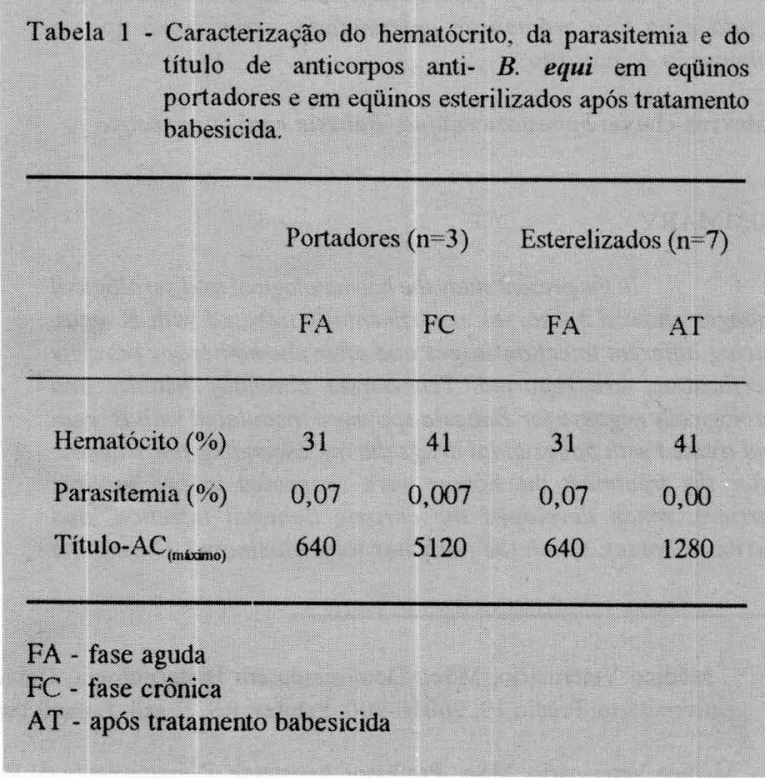




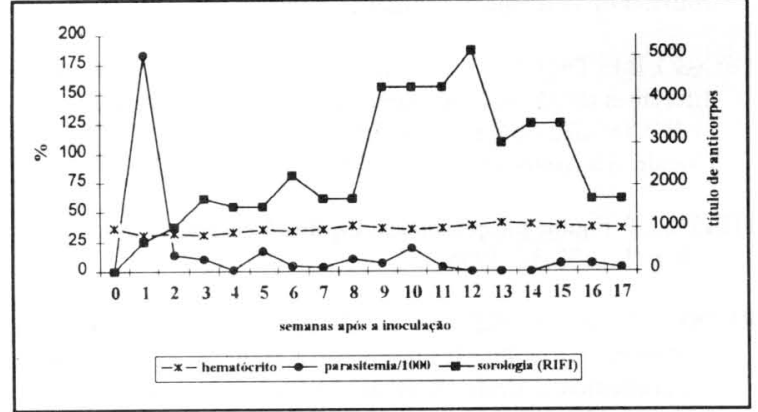

Figura 1 - Hematćcrito, parasitemia e título de anticorpos em eqüinos inoculados experimentalmente com B. equi e, posteriormente, mantidos como portadores.

Durante este período, somente foram detectadas parasitemias $\geq 0,01 \%$. Considerando que durante a fase crônica os animais podem apresentar parasitemias inferiores a $0,01 \%$, estima-se os exames que resultaram negativos tenham apresentado diagnóstico falso negativo. Estes resultados concordam com BÖSE $\boldsymbol{e t}$ al. (1995) ao indicarem a baixa sensibilidade do exame de esfregaço sangüíneo, quando comparado com outras técnicas de diagnóstico direto.

Os animais que foram esterilizados apresentavam-se negativos no exame de esfregaços sangüíneos, 48 horas após o início do tratamento e com título máximo de anticorpos (1280) por RIFI na quarta semana após a inoculação. O título de anticorpos começou a decrescer a partir do $28^{\circ} \mathrm{DAI}$, sendo que os sete eqüinos tornaram-se soronegativos até o $121^{\circ}$ DAI (Figura 2).

Foi observada uma relação inversa entre o hematócrito e o título de anticorpos durante a fase aguda da infeção, cujas oscilações provavelmente estejam relacionadas com a dinâmica do parasito na circulação. DE WAAL et al. (1987) e KUTTLER $\boldsymbol{e t}$ al. (1986) afirmaram que a queda do hematócrito é um

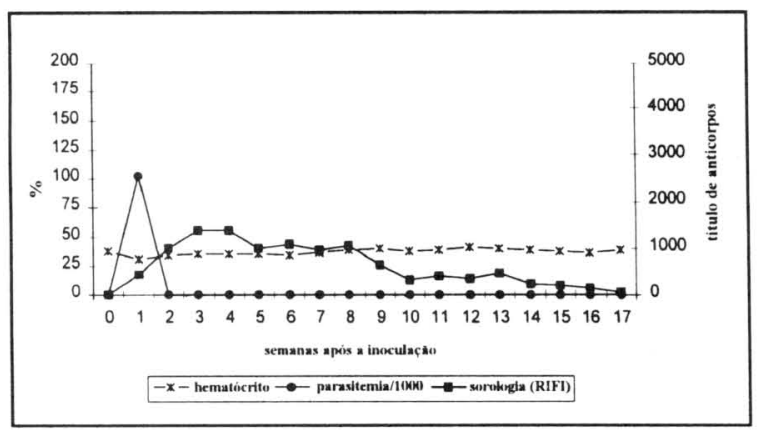

Figura 2 - Hematócrito, parasitemia e título de anticorpos em eqüinos inoculados experimentalmente $\operatorname{com} B$. equi e, posteriormente, esterilizados com drogas babesicidas. sensível indicador do início de alterações patológicas induzidas pelo parasito e que a ocorrência de parasitemia por $\boldsymbol{B}$. equi está relacionada com aumento dos títulos de anticorpos e queda do hematócrito. No entanto, neste trabalho, as alterações de hematócrito somente foram significativas durante a fase aguda da infecção.

Com base nos resultados obtidos, foi possível concluir que o título de anticorpos está diretamente relacionado com a multiplicação do parasito, mesmo durante baixas parasitemias; o hematócrito cai rapidamente durante a fase aguda da infecção porém, não sofre alterações significativas durante a fase crônica; a técnica de esfregaço sangüíneo possui baixa sensibilidade na detecção do parasito durante baixas parasitemias.

Considerando o exposto, sugere-se que técnicas mais sensíveis e seguras devam ser adotadas para diagnóstico da enfermidade. Atualmente, técnicas de biologia molecular têm representado uma importante ferramenta no diagnóstico de diversas enfermidades. A reação em cadeia da polimerase (PCR) (SAIKI et al., 1988) tem se mostrado mais sensível, específica e rápida no diagnóstico de $\boldsymbol{B}$. equi do que os testes até então empregados (NICOLAYEWSKY et al., 1995).

No diagnóstico da babesiose eqüina, a análise isolada de hematócrito e título de anticorpos, limita a interpretação do estágio exato da infecção. Por outro lado, a dificuldade no diagnóstico pode ser aumentada em virtude da baixa sensibilidade do exame de esfregaço sangüíneo na detecção do parasito. Considerando estas limitações, os autores tem trabalhado no desenvolvimento de testes de biologia molecular que ofereçam maior segurança na detecção direta do parasito (NICOLAYEWSKY et al., 1995; DUTRA et al., 1996; CUNHA et al., 1997).

\section{REFERÊNCIAS BIBLIOGRÁFICAS}

BÖSE, R., JORGENSEN, W, K., DALGLIESH, R, J., et al. Current state and future trends in the diagnosis of babesiosis. Veterinary Parasitology, v. 57, p. 61-74, 1995

BRÜNING, A. Equine piroplasmosis an update on diagnosis, treatment and prevention. British Veterinary Journal, v. 152 p. $139-151,1996$.

CUNHA, C.W., DEllagostiN, O.A., OZAKI L.S., et al. Caracterização do DNA extracromossomal de Babesia equi. In: I CONGRESSO DE PÓS-GRADUAÇÃO EM CIÊNCIAS AGRÁRIAS, 1997. Pelotas, RS. Anais... Pelotas, UFPel, 1997. $161 \mathrm{p}$.

CUNHA, C.W. Babesiose Equina: padronização da reação de imunofluorescência para sorodiagnóstico e levantamento epidemiológico em eqüinos Puro Sangue Inglês. Pelotas - RS. 57 p. Tese (Mestrado em Veterinária) Curso de Pós-graduação em Veterinária. Universidade Federal de Pelotas, 1993. 
DE WAAL, D.T. Equine piroplasmosis: A Review. British Veterinary Journal, v. 148, p. 6-14, 1992.

DE WAAL, D.T., VAN HEERDEN, J., POTGIETER, F.T. An investigation into the clinical pathological changes and serological response in horses experimentally infected with Babesia equi and Babesia caballi. Onderstepoort Journal of Veterinary, v. 54, p. $561-568,1987$.

DUTRA, C.L., OSÓRIO, B.L., SILVA, S.S., et al Desenvolvimento do diagnóstico de Babesia equi pela reação em cadeia da polimerase (PCR). In: V CONGRESSO DE INICIAÇÃO CIENTÍFICA, 1996. Pelotas, RS Anais... FURG, UFPEL, UCPEL, 1996, $257 \mathrm{p}$.

FRIEDHOFF, K.T. Hemoparasites of equines: impact on international trade of horses. Revue Scientifique et ThecniqueOffice Intemational des Epizooties, v. 9, p.1187-1194, 1990.

KUTTLER, K.L., GIPSON, C.A., GOFF, W.L., et al. Experimental Babesia equi infection in mature horses. Anerican Journal of Veterinary Research, v. 47, n. 8, p. 1668-1670, 1986.

OLADOSU, L, A., OLUFEMI, B, E. Haematology of experimental babesiosis and ehrlichiosis in steroid immunossupred horses.
Journal of Veterinary Medicine, v. 39, p. 345-352, 1992

OSÓRIO, B.L., DUTRA, C.L., PIMENTEL, C.A et al Avaliação de diferentes drogas no tratamento de infecções por Babesia equi. In: IV CONGRESSO DE INICIAÇÃO CIENTÍFICA, 1995. Rio Grande, RS Anais... FURG, UFPEL, UCPEL, 1995, 219 p.

PHIPPS, L.P. Equine piroplasmosis, Equine Veterinary Education, v. 8, n. 1, p. 33-36, 1995.

RUDOLPH, W., CORREA, J., ZURITA, L., et al Equine piroplasmosis: leukocytic response to Babesia equi (Laveran, 1901) infection in Chile. British Veterinary Journal, v. 131, $\mathrm{n}$. 5, p. $601-609,1975$

SAIKI, R.K., GELFAND, D.H., STOFFEL, S., et al. Primer-directed enzymatic amplification of DNA with a thermostable DNA polymerase. Science, v.239, p.487-491, 1988.

NICOLAIEWSKY, T.B., IKUTA, N., LUNGE, V.R., et al. Desenvolvimento de uma metodologia para diagnóstico molecular de Babesia equi pela Reação em Cadeia da Polimerase (PCR) em amostras de sangue de eqüinos. In: IX SEMINÁRIO BRASILEIRO DE PARASITOLOGIA VETERINÁRIA, 1995. Campo Grande, MS. Anais... Campo Grande: CBPV, 1995, 349 p.

Ciência Rural, v. 28, n. 2, 1998. 